\title{
Solar Radiation Interception, Dry Matter Production and Yield among Different Plant Densities of Arachis spp. in Ibadan, Nigeria
}

\author{
Kolapo 0. Oluwasemire ${ }^{1 *}$, George 0. Odugbenro ${ }^{1,2}$ \\ ${ }^{1}$ Department of Agronomy, Faculty of Agriculture and Forestry, University of Ibadan, Ibadan, Nigeria \\ ${ }^{2}$ College of Resources and Environment, Northeast Agricultural University, Harbin, China \\ Email: ${ }^{*}$ kooluwasemire@yahoo.com
}

Received 24 June 2014; revised 26 July 2014; accepted 7 August 2014

Copyright (C) 2014 by authors and Scientific Research Publishing Inc.

This work is licensed under the Creative Commons Attribution International License (CC BY). http://creativecommons.org/licenses/by/4.0/

(c) (7) Open Access

\section{Abstract}

The production of grain legumes is becoming a popular practice in the humid south western Nigeria. Apart from the decreasing trends observed in rainfall amount and duration as a result of climate change, solar radiation interception also constitutes a limitation to crop production because of persistent cloud cover. A trial was conducted at the University of Ibadan experimental site to determine the effect of different plant densities of Arachis spp. on solar radiation interception, dry matter production and yield in Ibadan, Nigeria with the aim of ascertaining the best practice for groundnut production in the zone. The treatments were three plant spacings $(60 \mathrm{~cm} \times 20 \mathrm{~cm}, 75$ $\mathrm{cm} \times 20 \mathrm{~cm}$ and $75 \mathrm{~cm} \times 40 \mathrm{~cm}$ ), and three Arachis varieties (Samnut 10, Samnut 21 and Pintoi) arranged in a split plot, randomized complete block design with Arachis varieties as the main plot while plant densities formed the subplot and replicated three times. Growth parameters (number of leaves, dry leaf weight and dry stem weight) were measured at two weeks interval while yield parameters (number of pods, dry pod weight, dry seed weight and total dry matter) were determined at harvest. Intercepted radiation by plants (PAR) was also taken along with the growth parameters. The highest light interception from 42 - 105 days after planting (DAP) among the Arachis spp. was recorded by Samnut 10, while at $42-87$ DAP, plant density of $75 \mathrm{~cm} \times 20 \mathrm{~cm}$ had the highest light interception. Dry matter production increased with light interception and was highest at 105 DAP when light interception was between $55 \%$ and $60 \%$ for all Arachis varieties and all plant densities. In terms of pod weight and grain yield, Samnut 10 performed better than Samnut 21 and also recorded the highest Radiation Use Efficiency (RUE) for pod, seed and total dry matter. However, Arachis pintoi, a sterile and forage plant with slower growth rate served as a cover crop *Corresponding author. 
capable of replenishing soil nutrients and physical properties.

\title{
Keywords
}

\author{
Radiation Use Efficiency, Arachis spp., Plant Densities, Solar Radiation Interception
}

\section{Introduction}

Groundnut is a major crop grown in the arid and semi arid zones of Nigeria. It is either grown for its nut, oil or its vegetative residue (haulms). Groundnut production is influenced by several environmental factors, especially moisture stress and temperature as reported by several authors [1]-[4]. It is an important oil seed crop as its seed contains $44 \%$ - $56 \%$ oil and 22\% - $30 \%$ protein on a dry seed basis [5]. The Arachis pintoi which is also a leguminous plant originally from Brazil is a multiple-use, prostrate, stoloniferous, perennial tropical legume [6], cultivated as a cover crop in orchards [7]. It forms a dense mat of rooted stolons that reduces weed invasion, controls erosion [8] and improves soil fertility through nitrogen fixation [9]. Unlike many other tropical legumes, A. pintoi is persistent and tolerant of acidic conditions, shading, drought and heavy grazing [6] [10].

Radiation Use Efficiency (RUE, $\mathrm{g} \cdot \mathrm{MJ}^{-1}$ ) is defined as the ratio of accumulated crop mass (i.e. dry matter) to cumulative intercepted solar radiation. It is a key factor in the determination of the photosynthetic performance of plants growing in any environment. Leaf area development is critical for maximum interception of solar radiation and the achievement of high crop productivity. Under well-watered conditions and ample nutrition, in the absence of pest and diseases, maize yield had been shown to be closely related to the amount of radiation intercepted [11] [12].

Soil water and solar energy are the basic atmospheric resources required for crop production. Plants can maximize canopy light interception by increasing both leaf surface area and the efficiency of light interception for each unit of leaf area [13]-[15]. Interception efficiency of both direct and diffuse irradiance increases on leaves with horizontal laminae (planophyllous leaf architecture) [16] [17]. In groundnut stands, interception of radiation and the efficiency of its conversion to stand biomass (Radiation Use Efficiency) decrease with increasing saturation deficit in the soil [18], and also in cells and tissues [19]. Considering the several factors that contribute to the success of Arachis spp., management decisions regarding variety selection and plant spacing can have strong effects on the development and yield of the crop. The objectives of this study are therefore to determine the effects of different plant spacing on the growth, development and yield of different varieties of Arachis and relate the amount of solar radiation intercepted and used on dry matter production and yield in Ibadan, South West Nigeria.

\section{Materials and Methods}

The experimental design was a split plot in randomized complete block design. Three varieties of Arachis (Samnut 10, Samnut 21 and Pintoi) were the main-plot treatments while three spacings $(75 \mathrm{~cm} \times 40 \mathrm{~cm}, 75 \mathrm{~cm} \times$ $20 \mathrm{~cm}$ and $60 \mathrm{~cm} \times 20 \mathrm{~cm}$ ) constituted the sub-plots. There were three replicates. The total land area used for the experiment was $(48 \mathrm{~m} \times 23 \mathrm{~m})$. Each block had nine plots with a dimension of $5 \mathrm{~m} \times 4 \mathrm{~m}$, intra boundary spacing of $1 \mathrm{~m}$, inter boundary spacing of $2 \mathrm{~m}$ and guard boundary of $2 \mathrm{~m}$, consisting of 27 plots in all. Groundnut was sown at one seed per hole (seed viability is 100 percent) on ridges on August 01, 2011 while pintoi was planted vegetatively using stem cuttings on ridges on August 19, 2011 after the emergence of groundnut.

Soil samples at the depth of $0-15 \mathrm{~cm}$ were taken randomly on each plot before planting. The soil samples were bulked, air dried and sieved through a $2 \mathrm{~mm}$ and $0.5 \mathrm{~mm}$ sieves and analysed for $\mathrm{pH}\left(\mathrm{H}_{2} \mathrm{O}\right.$ and $\left.\mathrm{KCl}\right)$, Organic carbon by Walkey Black method, exchangeable base (Potassium, Sodium, Magnesium and Calcium) by flame photometer and Atomic Absorption Spectrophotometer, available phosphorous by Bray P-1 method, total nitrogen by Micro-Kjeldhal method, and extractable micronutrients (Iron, copper, Manganese and zinc) by Atomic Absorption Spectrophotometer.

Undisturbed soil samples at the depth of $0-15 \mathrm{~cm}$ were also taken on the plot with the aid of a core sampler to determine bulk density and saturated hydraulic conductivity using the constant head method. The particle size analysis was also carried out by the hydrometer method. 


\section{Plant Sampling and Analysis}

Plant sample collection commenced at about 6 weeks after planting (WAP) and was done at 2 weeks interval. On each sampling occasion, one plant stand was randomly taken per plot outside the designated final harvest area. The selected plant stand was carefully uprooted, separated into leaves, stem and pods and oven dried at $70^{\circ} \mathrm{C}$ to a constant weight to determine component dry weights. The leaf area per plant was determined from sampled area using a CI-202 Area Meter (CI-202, CID, Inc., USA) and used for calculating the leaf area index (LAI) per plant stand. The total numbers of leaves per plant stand were also recorded. Other data collected include daily records of solar radiation, daily incident photosynthetic active radiation (PAR), crop phenology, maximum and minimum temperature and daily rainfall.

Photosynthetic Active Radiation (PAR) was measured from six weeks after planting using 0.8-m-long Sunfleck Ceptometer (Decagon Device Inc., Pullman, WA Model \#SF-80), and six readings were taken at 2 weeks interval.

Incoming PAR (I) was measured $1 \mathrm{~m}$ above the canopy. Three transmitted measurements (T) were taken with the ceptometer positioned on ridge, below plant between two ridges and across two ridges in each plot within the final harvest area. The ceptometer was inverted $1 \mathrm{~m}$ above the plant canopy to measure the reflected PAR (R). Daily solar radiation (SR) data was also collected at the International Institute of Tropical Agriculture (IITA) Ibadan meteorological weather station.

Radiation measurements were taken at solar noon under clear skies above and below the canopy to comprise a measurement pair of which the ratio gives the percentage PAR reaching the ground, from which the interception was calculated. The measurement sites were tagged plants within the designated final harvest area in each plot, which were taken on three plots to give a replicated treatment. The average of three transmitted PAR measurements with the ceptometer placed between, within and diagonally below the canopy of each plot was used to obtain periodic transmitted PAR measurement. The ceptometer was also inverted $1.0 \mathrm{~m}$ above the canopy to measure reflected PAR from the canopy-soil scene. Precautions taken and difficulties met with such equipment were as listed by Mungai et al. [20].

At Ibadan, the coefficient of 0.50 was used to estimate PAR from measured net radiation values recorded at the IITA weather station [21]. Daily radiation absorbed by the canopy was then determined from the calculated extinction coefficient, incoming and reflected PAR, and interpolated leaf area index estimated between radiation measurements. Accumulated dry matter (DM) is a function of accumulated daily absorbed PAR and Radiation Use Efficiency (RUE). RUE was calculated by regressing dry matter accumulation against intercepted PAR [22].

$$
\mathrm{DM}=\mathrm{RUE} \times \mathrm{PAR}
$$

Therefore: $\quad$ RUE $=$ DM/PAR

Leaf area index was measured alongside with the growth analysis every two weeks starting from the sixth week of planting to the fourteenth week.

All data collected were subjected to analysis of variance (ANOVA). Least significant difference (LSD) was used for mean separation at $5 \%$ level of significance.

\section{Results and Discussion}

\subsection{Soil and Weather Situations}

The values of the physical and chemical properties of the soil used for experiment are shown in Table 1 . The soil belongs to the textural class of loamy sand with $838 \mathrm{~g} \cdot \mathrm{kg}^{-1} \mathrm{~s}$ and, $79 \mathrm{~g} \cdot \mathrm{kg}^{-1}$ silt and $83 \mathrm{~g} \cdot \mathrm{kg}^{-1}$ clay, with good drainage which is ideal for groundnut production and harvesting [23]. The soil chemical analysis result gave total nitrogen of $1.7 \mathrm{~g} \cdot \mathrm{kg}^{-1}$ which is medium, soil $\mathrm{pH}\left(\mathrm{H}_{2} \mathrm{O}\right)$ of 6.0 (medium acid), organic carbon of 16.3 $\mathrm{g} \cdot \mathrm{kg}^{-1}$ is high while available phosphorus of $34 \mathrm{mg} \cdot \mathrm{kg}^{-1}$ is also high. Soil potassium is $0.3 \mathrm{cmol} \cdot \mathrm{kg}^{-1}$ in the medium availability range and calcium of $33.8 \mathrm{cmol} \cdot \mathrm{kg}^{-1}$ which is high [24]. The values of soil nutrients are in the available forms to sustain a good crop of groundnut without additional nutrient supply to the soil [23], hence there was no soil nutrient amendment application to the trial.

The weather condition during the cropping season of 2011 is shown in Table 2. The range of the mean monthly maximum air temperature between August and November were ideal for the growth, development, maturity and harvest of groundnut at Ibadan [25]. Warm night temperature range of $21^{\circ} \mathrm{C}$ to $24^{\circ} \mathrm{C}$ with adequate moisture observed during the growing season ensured good growth and development of groundnut (Table 2). 
Table 1. Physical and chemical properties of soil at experimental site.

\begin{tabular}{|c|c|}
\hline Parameter & Value \\
\hline $\mathrm{pH}\left(\mathrm{H}_{2} \mathrm{O}\right) 1: 1$ & 6.0 \\
\hline Total Nitrogen $\left(\mathrm{g} \cdot \mathrm{kg}^{-1}\right)$ & 1.7 \\
\hline Organic Carbon $\left(\mathrm{g} \cdot \mathrm{kg}^{-1}\right)$ & 16.3 \\
\hline Available Phosphorus $\left(\mathrm{mg} \cdot \mathrm{kg}^{-1}\right.$ ) & 34 \\
\hline \multicolumn{2}{|l|}{ Extractable Micronutrients (mg $\mathrm{kg}^{-1}$ ) } \\
\hline $\mathrm{Fe}$ & 165 \\
\hline $\mathrm{Mn}$ & 354 \\
\hline $\mathrm{Zn}$ & 14 \\
\hline $\mathrm{Cu}$ & 6 \\
\hline \multicolumn{2}{|l|}{ Exchangeable bases $\left(\mathrm{cmol} \cdot \mathrm{kg}^{-1}\right)$} \\
\hline $\mathrm{K}$ & 0.3 \\
\hline $\mathrm{Na}$ & 0.6 \\
\hline $\mathrm{Ca}$ & 33.8 \\
\hline $\mathrm{Mg}$ & 2.8 \\
\hline \multicolumn{2}{|l|}{ Particle Size Distribution $\left(\mathrm{g} \cdot \mathrm{kg}^{-1}\right)$} \\
\hline Sand & 838 \\
\hline Silt & 79 \\
\hline Clay & 83 \\
\hline Textural Class (USDA) & Loamy Sand \\
\hline Bulk Density $\left(\mathrm{Mg} \cdot \mathrm{m}^{-3}\right)$ & 1.36 \\
\hline Saturated Hydraulic Conductivity $\left(\mathrm{cm} \cdot \mathrm{sec}^{-1}\right)$ & $4.72 \times 10^{-3}$ \\
\hline
\end{tabular}

Table 2. Monthly mean values of solar radiation, maximum and minimum air temperatures, monthly total rainfall, and rainfall days for the year 2011.

\begin{tabular}{cccccc}
\hline Month & Radiation $\left(\mathrm{MJ} \cdot \mathrm{m}^{-2} \cdot\right.$ day $\left.^{-1}\right)$ & $\begin{array}{c}\text { Maximum } \\
\text { Temperature }\left({ }^{\circ} \mathrm{C}\right)\end{array}$ & $\begin{array}{c}\text { Minimum } \\
\text { Temperature }\left({ }^{\circ} \mathrm{C}\right)\end{array}$ & $\begin{array}{c}\text { Total Rainfall } \\
(\mathrm{mm})\end{array}$ & Rainfall Days \\
\hline January & 5.2 & 32.9 & 19.4 & 0.0 & 0 \\
February & 6.8 & 33.7 & 22.9 & 134.6 & 6 \\
March & 6.3 & 33.8 & 23.7 & 72.3 & 5 \\
April & 3.9 & 32.8 & 23.1 & 103.0 & 6 \\
May & 3.9 & 32.3 & 22.8 & 146.1 & 14 \\
June & 3.1 & 30.5 & 22.5 & 224.4 & 18 \\
July & 3.2 & 28.1 & 21.8 & 156.4 & 22 \\
August & 2.4 & 27.8 & 21.1 & 314.9 & 16 \\
September & 8.6 & 29.6 & 22.2 & 280.9 & 14 \\
October & 6.9 & 30.0 & 21.7 & 262.4 & 21 \\
November & 10.7 & 32.4 & 23.6 & 8.0 & 2 \\
December & 16.1 & 33.5 & 19.7 & 0.0 & 0 \\
Total & & & & 1703.3 & 124 \\
\hline
\end{tabular}

Source: International institute of tropical agriculture (IITA), (2011). 
Total energy (Solar radiation) intercepted during the season in Ibadan was $77.1 \mathrm{MJ} \cdot \mathrm{m}^{-2} \cdot \mathrm{day}^{-1}$ as shown in Table 2. The average solar radiation was $6.43 \mathrm{MJ} \cdot \mathrm{m}^{-2} \cdot$ day $^{-1}$ with 16.1 and $2.4 \mathrm{MJ} \cdot \mathrm{m}^{-2} \cdot$ day $^{-1}$ as the highest and lowest recorded values respectively. Solar radiation was very low within the month of August when planting was done but later rose steadily until it reached its highest value $\left(16.1 \mathrm{MJ} \cdot \mathrm{m}^{-2} \cdot \mathrm{day}^{-1}\right)$ in December. The occurrence of heavy rainfall and persistent cloud cover in August would have been responsible for the observed mean low solar radiation value $\left(2.4 \mathrm{MJ} \cdot \mathrm{m}^{-2} \cdot \mathrm{day}^{-1}\right)$. Incident solar radiation was generally lower than required by groundnut in Ibadan during the cropping season as compared to the less humid northern Nigeria $(>16.1$ $\mathrm{MJ} \cdot \mathrm{m}^{-2} \cdot$ day $^{-1}$ ) where groundnut has shown better adaptation and is grown extensively [26].

\subsection{Light Interception and Dry Matter Production}

The trend of light interception for the three Arachis varieties used for the experiment is shown in Figure 1. At 42 DAP, Samnut 10 had the highest percentage light interception, followed by Samnut 21, and least by Pintoi which is a forage plant that establishes slowly and intercepts solar radiation at a lower rate when compared to the other Arachis species [27]. However the highest percentage light interception from 70 - 105 DAP indicated that Samnut 10 recorded the highest percentage light interception, followed by Samnut 21, and least by Pintoi (Figure 1). The trend of Total dry matter production by the Arachis spp was also a function of total intercepted radiation [28], which determined their capacity to store photosynthates for development. Samnut 10, showed a greater tendency of producing more vegetative parts than the other Arachis varieties (Samnut 21 and Pintoi).

The trend of light interception for the three plant densities is shown in Figure 2. At 42 DAP, plant density of $75 \mathrm{~cm} \times 20 \mathrm{~cm}$ had the highest percentage light interception, followed by $60 \mathrm{~cm} \times 20 \mathrm{~cm}$ and least by the widest spacing of $75 \mathrm{~cm} \times 40 \mathrm{~cm}$. However, at 56 DAP, plant density of $75 \mathrm{~cm} \times 40 \mathrm{~cm}$ had the highest percentage of light interception from early cover spread, closely followed by $75 \mathrm{~cm} \times 20 \mathrm{~cm}$, and least by $60 \mathrm{~cm} \times 20 \mathrm{~cm}$. The highest percentage light interception from $70-87$ DAP showed that plant density of $75 \mathrm{~cm} \times 20 \mathrm{~cm}$ recorded the highest light interception, and it was significantly higher than $75 \mathrm{~cm} \times 40 \mathrm{~cm}$ and $60 \mathrm{~cm} \times 20 \mathrm{~cm}$ at 70 DAP. Also at 105 DAP, plant density of $75 \mathrm{~cm} \times 40 \mathrm{~cm}$ had the highest percentage light interception, followed by 60 $\mathrm{cm} \times 20 \mathrm{~cm}$, and least by $75 \mathrm{~cm} \times 20 \mathrm{~cm}$. The population density had a moderate effect on the conversion of intercepted radiation to dry matter, but the influence on production seem to be mainly through leaf area index [29].

The interactive effects between three varieties and three plant densities on light interception (Figure 3) showed that Samnut 10 and Samnut 21 were not different from each other but were both significantly higher than Pintoi for the plant density of $60 \mathrm{~cm} \times 20 \mathrm{~cm}$ at 70 DAP. However, for the plant density of $75 \mathrm{~cm} \times 20 \mathrm{~cm}$, Samnut 10 was significantly higher in intercepted radiation than Samnut 21 and Pintoi, while for the plant spacing of $75 \mathrm{~cm} \times 40 \mathrm{~cm}$, the three Arachis varieties showed no difference. The Samnut 10, which is late maturing showed a better adaptation to the moist humid zone of western Nigeria with higher light interception capability at relatively wide spacing to produce the highest dry matter among the three Arachis spp. [21].

The trend of dry matter production for Arachis varieties (Figure 4) indicated the highest total dry matter production values from 42 - 105 DAP by Samnut 10, followed by Samnut 21, and both groundnut varieties were significantly higher than Pintoi. Dry matter production generally increased with percentage light interception and was highest at 105 DAP when the Arachis spp. were at maturity [27].

The effect of planting density on trend of dry matter accumulation is shown in Figure 5. At 42 and 56 DAP, plant density of $60 \mathrm{~cm} \times 20 \mathrm{~cm}$ was significantly higher than $75 \mathrm{~cm} \times 20 \mathrm{~cm}$ and $75 \mathrm{~cm} \times 40 \mathrm{~cm}$, while $75 \mathrm{~cm} \times$ $20 \mathrm{~cm}$ was also significantly higher than $75 \mathrm{~cm} \times 40 \mathrm{~cm}$. Plant density of $60 \mathrm{~cm} \times 20 \mathrm{~cm}$ was not different from $75 \mathrm{~cm} \times 20 \mathrm{~cm}$ but was significantly higher than $75 \mathrm{~cm} \times 40 \mathrm{~cm}$ at 70 and 87 DAP. However, at 105 DAP, plant density of $60 \mathrm{~cm} \times 20 \mathrm{~cm}$ was different from $75 \mathrm{~cm} \times 20 \mathrm{~cm}$ and $75 \mathrm{~cm} \times 40 \mathrm{~cm}$. Dry matter production for plant densities also increased with percentage light interception and was highest at 105 DAP. Although incident incoming solar radiation values were generally low (Table 1), the trend of dry matter accumulation over time was with increasing interception of solar radiation.

The trend of LAI for Arachis varieties is shown in Figure 6. The two groundnut varieties (Samnut 10 and Samnut 21) had similar leaf area indices and were significantly higher than Pintoi throughout the duration of crop life cycle. However, the trend of LAI for plant densities (Figure 7) was highest at 42 and 56 DAP for the plant density of $60 \mathrm{~cm} \times 20 \mathrm{~cm}$, closely followed by $75 \mathrm{~cm} \times 20 \mathrm{~cm}$; while both were significantly higher than was observed for $75 \mathrm{~cm} \times 40 \mathrm{~cm}$ spacing. At plant physiological maturity (105 DAP), plant densities of $60 \mathrm{~cm} \times$ $20 \mathrm{~cm}$ and $75 \mathrm{~cm} \times 20 \mathrm{~cm}$ were significantly higher in LAI than $75 \mathrm{~cm} \times 40 \mathrm{~cm}$ spacing. 

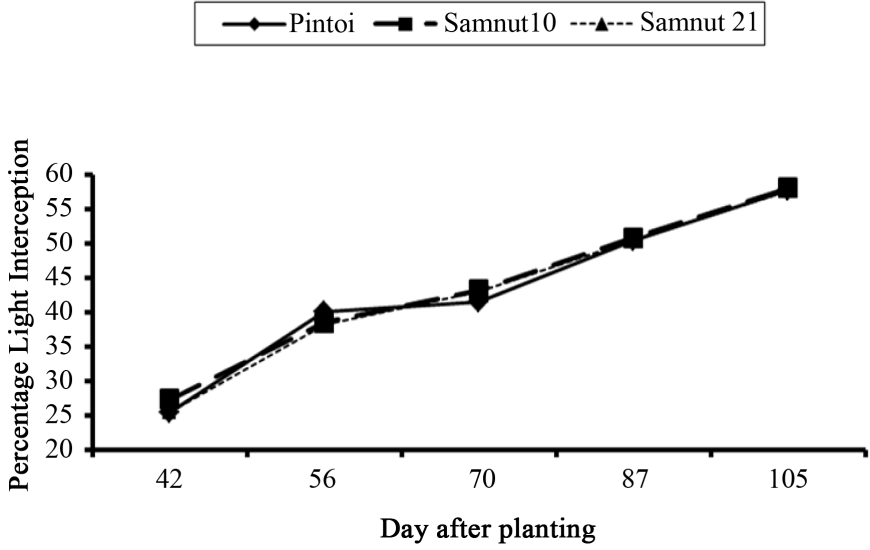

Figure 1. Trend of light interception for the three Arachis varieties (Pintoi, Samnut 10 and Samnut 21) during 2011 rainy season at Ibadan.

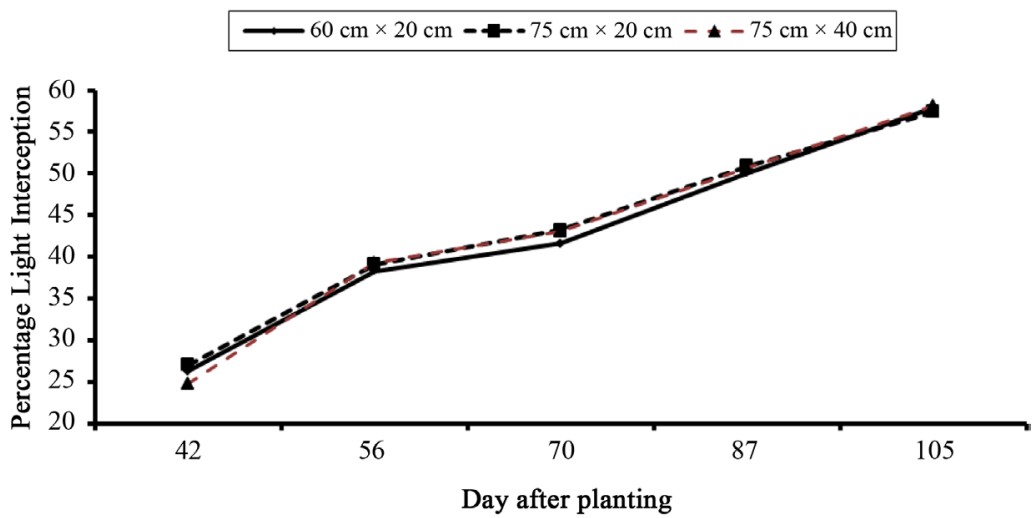

Figure 2. Trend of light interception for the three plant spacings $(60 \mathrm{~cm} \times 20 \mathrm{~cm}$, $75 \mathrm{~cm} \times 20 \mathrm{~cm}, 75 \mathrm{~cm} \times 40 \mathrm{~cm}$ ) of Arachis varieties during 2011 rainy season in Ibadan.

- Pintoi $\mathbf{\square}$ Samnut10 $\square$ Samnut21

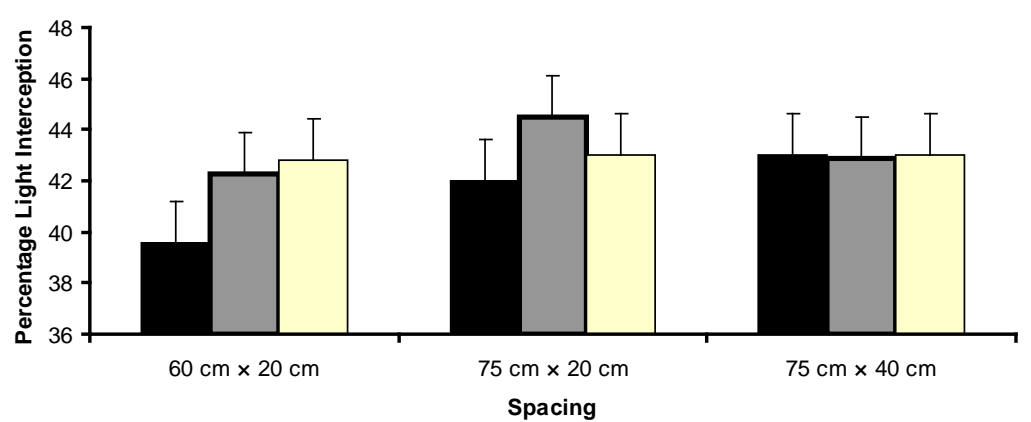

Figure 3. Variety $\times$ Spacing interaction for percentage light interception at 70 days after planting during 2011 rainy season. Extended vertical lines on bars represent $\mathrm{LSD} \leq 0.05$.

The interactive effects of variety and spacing on LAI at 56 DAP showed that Samnut 10 and Samnut 21 were significantly higher than Pintoi for the three plant densities $(60 \mathrm{~cm} \times 20 \mathrm{~cm}, 75 \mathrm{~cm} \times 20,75 \mathrm{~cm} \times 40 \mathrm{~cm}$ ) (Figure 8). Although the production of grain is more important that total dry matter from economic point of view, grain yield is always related to dry matter production over time. The generally low seasonal values of LAI, low dry matter production and pod yield s are expected from the Arachis spp which are C3 legume plants. These are 


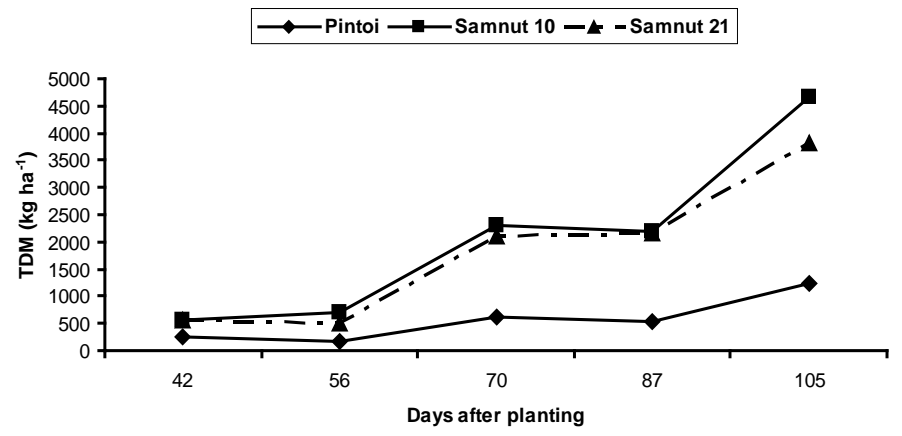

Figure 4. Trend of Total Dry Matter (TDM) accumulation (kg·ha ${ }^{-1}$ ) for Arachis varieties during 2011 rainy season.

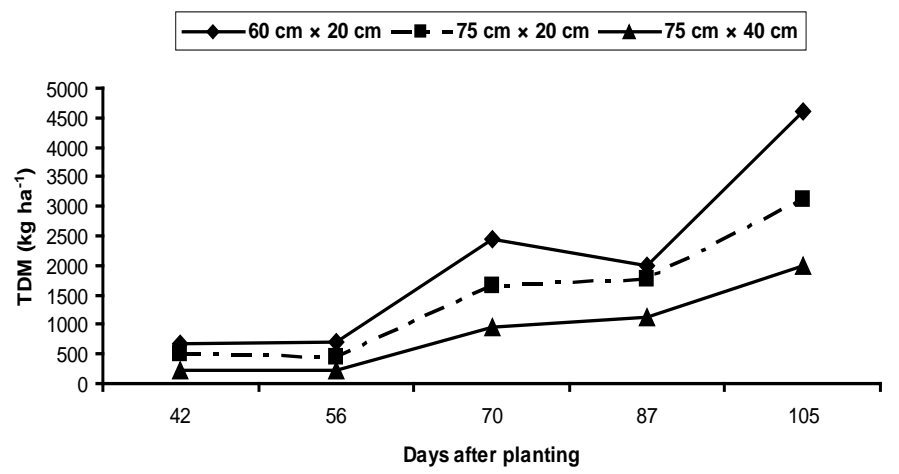

Figure 5. Trend of Total Dry Matter (TDM) accumulation (kg·ha ${ }^{-1}$ ) for plant spacings during 2011 reason season.

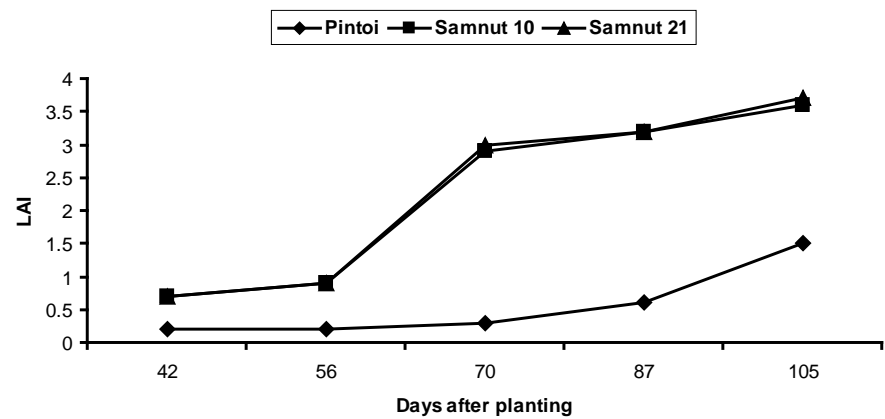

Figure 6. Trend of Leaf Area Index (LAI) for Arachis varieties during 2011 rainy season.

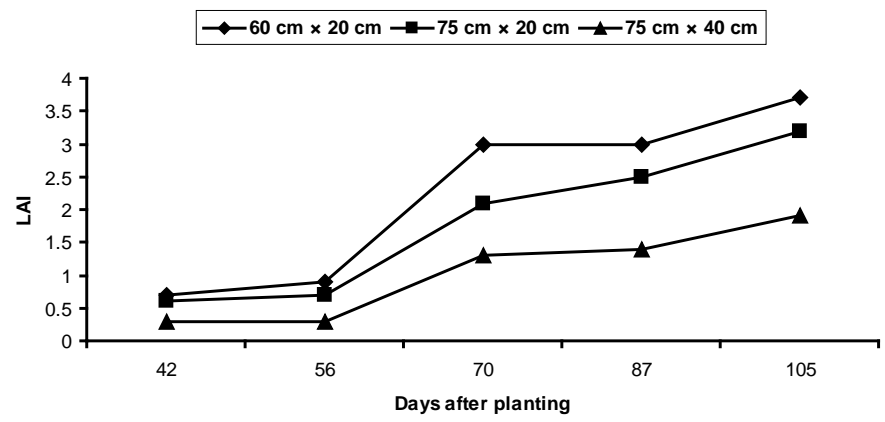

Figure 7. Trend of Leaf Area Index (LAI) for plant density during 2011 reason season. 
口intoi DSamnut10 ם Samnut21

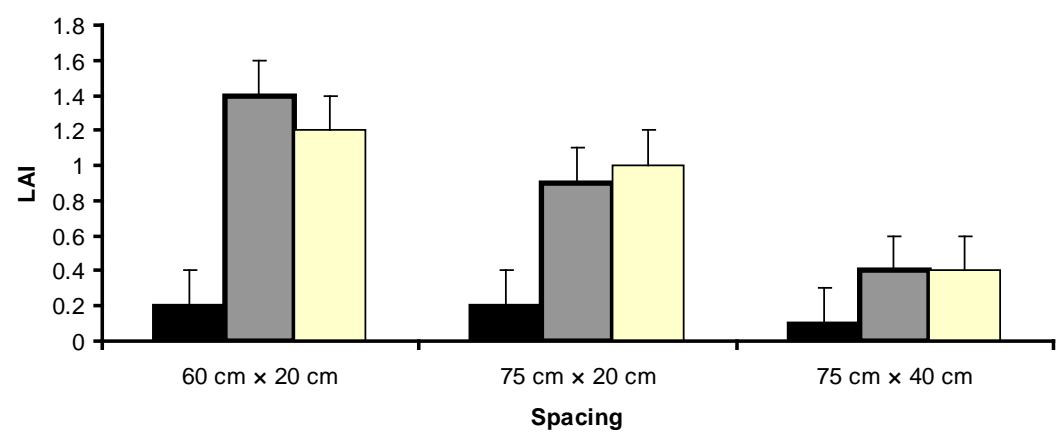

Figure 8. Variety $\times$ Spacing interaction for LAI at 56 days after planting during 2011 rainy season. Extended vertical lines on bars represent $\mathrm{LSD} \leq 0.05$.

justified with the low levels of incident radiation from excessive cloud cover in the humid environment of Ibadan and low levels of radiation intercepted during the cropping season [30] [31].

\subsection{Arachis Yield Parameters, Yield and RUE}

Comparison of means of yield parameters and yield are shown in Table 3. For the Arachis varieties used for the experiment, significant differences were observed for number of plants per metre square, leaf number, number of pods per plant, pod weight and haulm weight. However, the different plant densities did not have effect on yield and yield parameters of the groundnut varieties (except for the number of plants per metre square). Among the three plant spacings, $60 \mathrm{~cm} \times 20 \mathrm{~cm}$ was significantly higher than $75 \mathrm{~cm} \times 20 \mathrm{~cm}$ and $75 \mathrm{~cm} \times 40 \mathrm{~cm}$ at $(\mathrm{P}<$ 0.05 ) for number of plants per metre square, while for number of leaves, pods per plant, pod weight, grain weight, haulm weight and harvest index, no difference was observed.

The Radiation Use Efficiency (RUE) as the slope of the regression for dry weight $\left(\mathrm{g} \cdot \mathrm{m}^{-2} / \mathrm{kg} \cdot \mathrm{ha}^{-1}\right.$ ) and a function of the cumulative interception of stand biomass against cumulative interception absorbed by the stand are shown in Table 4. The higher amount of light intercepted corresponded to a higher tendency of the Arachis varieties to store up photosynthesis [32]. Hence Samnut 10 which had the highest percentage light interception stored more photosynthates as indicated by the highest TDM produced [33]-[35].

Table 3. Yield and yield parameters of Arachis spp. as affected by plant density during 2011 growing season.

\begin{tabular}{|c|c|c|c|c|c|c|c|c|}
\hline Variables & Plants $/ \mathrm{m}^{2}$ & $\begin{array}{l}\text { Number } \\
\text { of Leaves }\end{array}$ & Pods/Plant & $\begin{array}{l}\text { Pod Weight } \\
\text { (kg/ha) }\end{array}$ & $\begin{array}{l}\text { Grain Weight } \\
\text { (kg/ha) }\end{array}$ & $\begin{array}{l}\text { Haulm Weight } \\
\text { (kg/ha) }\end{array}$ & $\begin{array}{l}\text { Harvest } \\
\text { Index }\end{array}$ & $\begin{array}{l}\text { Threshing } \\
\text { Percentage }\end{array}$ \\
\hline \multicolumn{9}{|l|}{ Variety } \\
\hline Pintoi & 4 & 486 & - & - & - & 373 & - & - \\
\hline Samnut 10 & 11 & 706 & 508 & 1124 & 255 & 1367 & 0.17 & 22.3 \\
\hline Samnut 21 & 5 & 964 & 315 & 686 & 188 & 1669 & 0.16 & 30.5 \\
\hline LSD & 2.04 & 208 & 119.2 & 300.2 & 81 & 315.4 & 0.03 & 9.4 \\
\hline F. Prob. & $* * *$ & $* *$ & $* *$ & $* *$ & ns & $* * *$ & ns & ns \\
\hline \multicolumn{9}{|l|}{ Spacing } \\
\hline $60 \mathrm{~cm} \times 20 \mathrm{~cm}$ & 9 & 653 & 514 & 1064 & 243 & 1074 & 0.17 & 24.6 \\
\hline $75 \mathrm{~cm} \times 20 \mathrm{~cm}$ & 6 & 695 & 384 & 776.4 & 198 & 976 & 0.18 & 26.8 \\
\hline $75 \mathrm{~cm} \times 40 \mathrm{~cm}$ & 5 & 808 & 338 & 813.7 & 223 & 1359 & 0.15 & 27.8 \\
\hline LSD & 2.04 & 208.2 & 146.0 & 367.7 & 99.3 & 315.4 & 0.04 & 11.5 \\
\hline F. prob & $* *$ & ns & ns & ns & ns & ns & ns & ns \\
\hline
\end{tabular}

***Significant at $\mathrm{P}<0.001, * *$ significant at $\mathrm{P}<0.01$, ns: not significant at $\mathrm{P}<0.05$. 
Table 4. Radiation Use Efficiency (RUE) of Arachis varieties grown at different densities in Ibadan in 2011.

\begin{tabular}{ccccc}
\hline & \multicolumn{3}{c}{ Arachis Varieties } \\
\hline RUE $\left(\mathrm{kg} \cdot \mathrm{MJ}^{-1}\right)$ & Pintoi & Samnut 10 & Samnut 21 & LSD \\
\hline Pod & - & $3.8^{* *}$ & $2.3^{* *}$ & 1.0 \\
Seed & - & $2.2^{* *}$ & $1.3^{* *}$ & 0.6 \\
Total Dry Matter (TDM) & $0.8^{* * *}$ & $4.8^{* * *}$ & $4.2^{* * *}$ & 1.2 \\
Pod & & & $75 \mathrm{~cm} \times 40 \mathrm{~cm}$ \\
Seed & $60 \mathrm{~cm} \times 20 \mathrm{~cm}$ & $75 \mathrm{~cm} \times 20 \mathrm{~cm}$ & 1.8 & $\mathrm{~ns}$ \\
Total Dry Matter (TDM) & 2.4 & 1.9 & 1.0 & $\mathrm{~ns}$ \\
\hline
\end{tabular}

*** Significant at $\mathrm{P}<0.001$, **Significant at $\mathrm{P}=0.01$, ns: not significant at $\mathrm{P}<0.05$; Sterile plant (pod not produced).

Samnut 10 recorded the highest RUE value for pod and seed, followed by Samnut 21. However, the Pintoi variety used is sterile and did not produce pods or seeds. Samnut 10 also recorded the highest RUE value for total dry matter (TDM), followed by Samnut 21, and least by Pintoi.

\section{Conclusions}

The results obtained showed that no significant difference was found among the three plant densities used for the experiment with respect to yield.

Higher solar radiation intercepted increased Radiation Use Efficiency (RUE), dry matter production as well as yield among the different varieties of Arachis planted and the plant densities used. However, Samnut 10 recorded the highest RUE, dry matter as well as yield.

It can be concluded that out of the two groundnut varieties (Samnut 10 and Samnut 21) used for this experiment, Samnut 10 was significantly higher than Samnut 21 in terms of number of plants per meter square and yield (number of pods per plant and pod weight) and also had the highest harvest index, therefore it is recommended for planting in this agroecological zone.

\section{References}

[1] Simmonds, L.P. and Williams, J.H. (1989) Population, Water Use and Growth of Groundnut Maintained on Stored Water 11. Transpiration and Evaporation from Soil. Experimental Agriculture, 25, 63-75. http://dx.doi.org/10.1017/S0014479700016458

[2] Karim, M.F. (1990) Growth, Development and Light Interception of Bambara Groundnut (Vigna Substaranea L Verdc.) and Groundnut (Arachis hypogaea) in Relation to Soil Moisture. M.Sc. Thesis, University of Nottingham, Nottingham.

[3] Ravindra, V., Nautyal, P.C. and Joshi, Y.C. (1990) Physiological Analysis of Drought Resistance and Yield in Groundnut. Tropical Agriculture, 67, 290-296.

[4] Ntare, B.R., Williams, J.H. and Dougbedji, F. (2001) Evaluation of Groundnut Genotypes for Heat Tolerance under Yield Conditions in a Sahelian Environment Using a Simple Physiological Model for Yield. The Journal of Agricultural Sciences, 136, 81-88. http://dx.doi.org/10.1017/S0021859600008583

[5] Savage, G.P. and Keenan, J.I. (1994) The Composition and Nutritive Value Of groundnut Kernels. In: Smartt, J., Ed., The Groundnut Crop, Chapman and Hall, London.

[6] Baruch, Z. and Fisher, M.J. (1996) Effect of Planting Method and Soil Texture on the Growth And development of Arachis pintoi. Tropical Grasslands, 30, 395-401.

[7] Firth, D.J. and Wilson, G.P.M. (1995) Preliminary Evaluation of Species for Use as Permanent Ground Cover in Orchards on the North Coast of New South Wales. Tropical Grasslands, 29, 18-27.

[8] Dwyer, G.T., O’Hare, P.J. and Cook, B.G. (1989) Pinto’s Peanut: A Ground Cover for Orchards. Queensland Agricultural Journal, 115, 153-154.

[9] Thomas, R.J., Asakawa, N.M., Rondon, M.A. and Alarcon, H.F. (1997) Nitrogen Fixation by Three Tropical Forage Legumes in an Acid-Soil Savanna of Colombia. Soil Biology and Biochemistry, 29, 801-808. 
http://dx.doi.org/10.1016/S0038-0717(96)00212-X

[10] Jones, R.M. and Bunch, G.A. (2003) Experiences with Farm Pastures at the Former CSIRO Samford Research Station, South-East Queensland, and How These Relate to Results from 40 Years of Research. Tropical Grasslands, 37, 151164.

[11] Tollenaar, M. and Bruuselma, T.W. (1988) Efficiency of Maize Dry Matter Production during Periods of Complete Leaf Area Expansion. Agronomy Journal, 80, 580-585. http://dx.doi.org/10.2134/agronj1988.00021962008000040008x

[12] Muchow, R.C. (1989) Comparative Productivity of Maize, Sorghum and Pearl Millet in a Semi-Arid Tropical Environment I. Yield Potential. Field Crops Research, 20, 191-205. http://dx.doi.org/10.1016/0378-4290(89)90079-8

[13] Huber, H. and Stuefer, J.F. (1997) Shade-Induced Changes in the Branching Pattern of a Stoloniferous Herb: Functional Response or Allometric Effect? Oecologia, 110, 478-486. http://dx.doi.org/10.1007/s004420050183

[14] Knapp, A.K. and Smith, D.L. (1997) Leaf Angle, Light Interception and Water Relations. Demonstrating How Plants Cope with Multiple Resource Limitations in the Field. American Biology Teacher, 59, 365-368. http://dx.doi.org/10.2307/4450331

[15] Caliskan, S., Caliskan, M.E., Erturk, E. and Arioglu, H. (2008) Growth and Development of Virginia Type Groundnut Cultivars under Mediterranean Conditions. Acta Agriculturae Scandinavica Section B-Soil and Plant Science, 58, 105113.

[16] Pearcy, R.W. and Vallarades, F. (1999) Resource Acquisition by Plants: The Role of Crown Architecture. In: Press, M.C., Scholes, J.D. and Baker, M.G., Eds., Physiological Plant Ecology, Blackwell, MPG, Cornwall, 45-66.

[17] Valladares, F. and Pearcy, R.W. (2000) The Role of Crown Architecture for Light Harvesting and Carbon Gain in Extreme Light Environments Assessed with a Realistic 3-D Model. Anales del Jardín Botánico de Madrid, 58, 3-16.

[18] Collino, D.J., Dardanelli, J.L., Sereno, R. and Racca, R.W. (2001) Physiological Responses of Argentine Peanut Varieties to Water Stress. Light Interception, Radiation Use Efficiency and Partitioning of Assimilates. Field Crops Research, 70, 177-184. http://dx.doi.org/10.1016/S0378-4290(01)00137-X

[19] Ong, C.K., Simmonds, L.P. and Matthews, R.B. (1987) Responses to Saturation Deficit in a Stand of Groundnut (Arachis hypogaea L.). 2. Growth and Development. Annals of Botany, 59, 121-128.

[20] Mungai, D.N., Stigter, C.J., Coulson, C.L. and Ng’anga, J.K. (2000) Simply Obtained Global Radiation, Soil Temperature and Soil Miosture in an Alley Cropping System in Semi-Arid Kenya. Theoretical \& Applied Climatology, 65, 63-78. http://dx.doi.org/10.1007/s007040050005

[21] Marshall, B. and Willey, R.W. (1983) Radiation Interception and Growth in an Intercrop of Pearl Millet/Groundnut. Field Crop Research, 7, 141-160. http://dx.doi.org/10.1016/0378-4290(83)90018-7

[22] Giunta, F., Pruneddu, G. and Motzo, R. (2009) Radiation Interception and Biomass and Nitrogen Accumulation in Different Cereal and Grain Legume Species. Field Crops Research, 110, 76-84. http://dx.doi.org/10.1016/j.fcr.2008.07.003

[23] Weiss, E.A. (1983) Oil Seed Crops. Longman Inc., New York.

[24] Chude, V.O., Olayiwola, C., Daudu, P. and Ekeoma, A. (Eds.) (2012) Fertilizer Use and Management Practices for Crops in Nigeria. 3rd Edition, Federal Fertilizer Department (FFD), Federal Ministry of Agriculture and Rural Development, Abuja, 204.

[25] PCARRD (Philippine Council for Agriculture and Resources Research and Developemnt)/USDA (U.S. Department of Agriculture) (1986) Environmental Adaptation of Crops. PCARRD Book Series No. 37, Los Banos, Laguna.

[26] Misari, S.M., Boye-Goni, S. and Kaigama, B.K. (1988) Groundnut Improvement, Production, Management and Utilization in Nigeria: Problems and Prospects. First ICRISAT Regional Goundnut Meeting for West Africa, Niamey, 61-64.

[27] De la Cruz, R., Suarez, S. and Ferguson, J.E. (1994) The Contribution of Arachis pintoi as a Ground Cover in Some Farming Systems of Tropical America. In: Kerridge, P.C. and Hardy, B., Eds., Biology and Agronomy of Forage Arachis, CIAT, Cali, 102-108.

[28] Monteith, J.L. (1977) Climate and Efficiency of Crop Production in Britain. Philosophical Transactions of the Royal Society London B, 281, 277-294. http://dx.doi.org/10.1098/rstb.1977.0140

[29] Hay, R. and Porter, J. (2006) The Physiology of Crop Yield. 2nd Edition, Blackwell Publishing, Oxford.

[30] Wiegand, C.L., Gebermann, A.H., Gallo, K.P., Blad, B.L. and Dusek, D. (1990) Multisite Analysis of Spectral-Biophysical Data for Corn. Remote Sensing of Environment, 33, 1-16. http://dx.doi.org/10.1016/0034-4257(90)90051-M

[31] Daughtry, C.S.T., Gallo, K.P., Goward, S.N., Prince, S.D. and Kustas, W.P. (1992) Spectral Estimates of Absorbed Radiation and Phytomass Production in Corn and Soybean Canopies. Remote Sensing of Environment, 39, 141-152. 
[32] Black, C and Ong, C. (2000) Utilization of Light and Water in Tropical Agriculture. Agricultural and Forest Meteorology, 104, 25-47. http://dx.doi.org/10.1016/S0168-1923(00)00145-3

[33] Matthews, R.B., Harris, D., Williams, J.H. and Nageswara Rao, R.C. (1988) The Physiological Basis for Yield Differences between Four Genotypes of Groundnut (Arachis hypogaea) in Response to Drought. 2. Solar Radiation Interception and Leaf Movement. Experimental Agriculture, 24, 203-213. http://dx.doi.org/10.1017/S0014479700015957

[34] Haro, R.J., Otegui, M.E., Collino, D.J. and Dardanelli, J.L. (2007) Environmental Effects on Seed Yield Determination of Irrigated Peanut Crops: Links with Radiation Use Efficiency and Crop Growth Rate. Field Crops Research, 103, 217-228. http://dx.doi.org/10.1016/j.fcr.2007.06.004

[35] Canavar, Õ. and Kaynak, M.A. (2010) Growing Degree Day and Sunshine Radiation Effects on Peanut Pod Yield and Growth. African Journal of Biotechnology, 9, 2234-2241. 
Scientific Research Publishing (SCIRP) is one of the largest Open Access journal publishers. It is currently publishing more than 200 open access, online, peer-reviewed journals covering a wide range of academic disciplines. SCIRP serves the worldwide academic communities and contributes to the progress and application of science with its publication.

Other selected journals from SCIRP are listed as below. Submit your manuscript to us via either submit@scirp.org or Online Submission Portal.
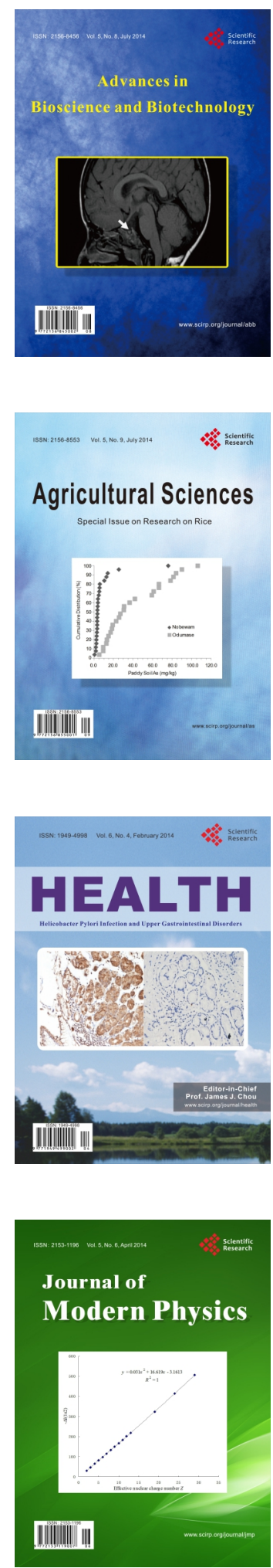
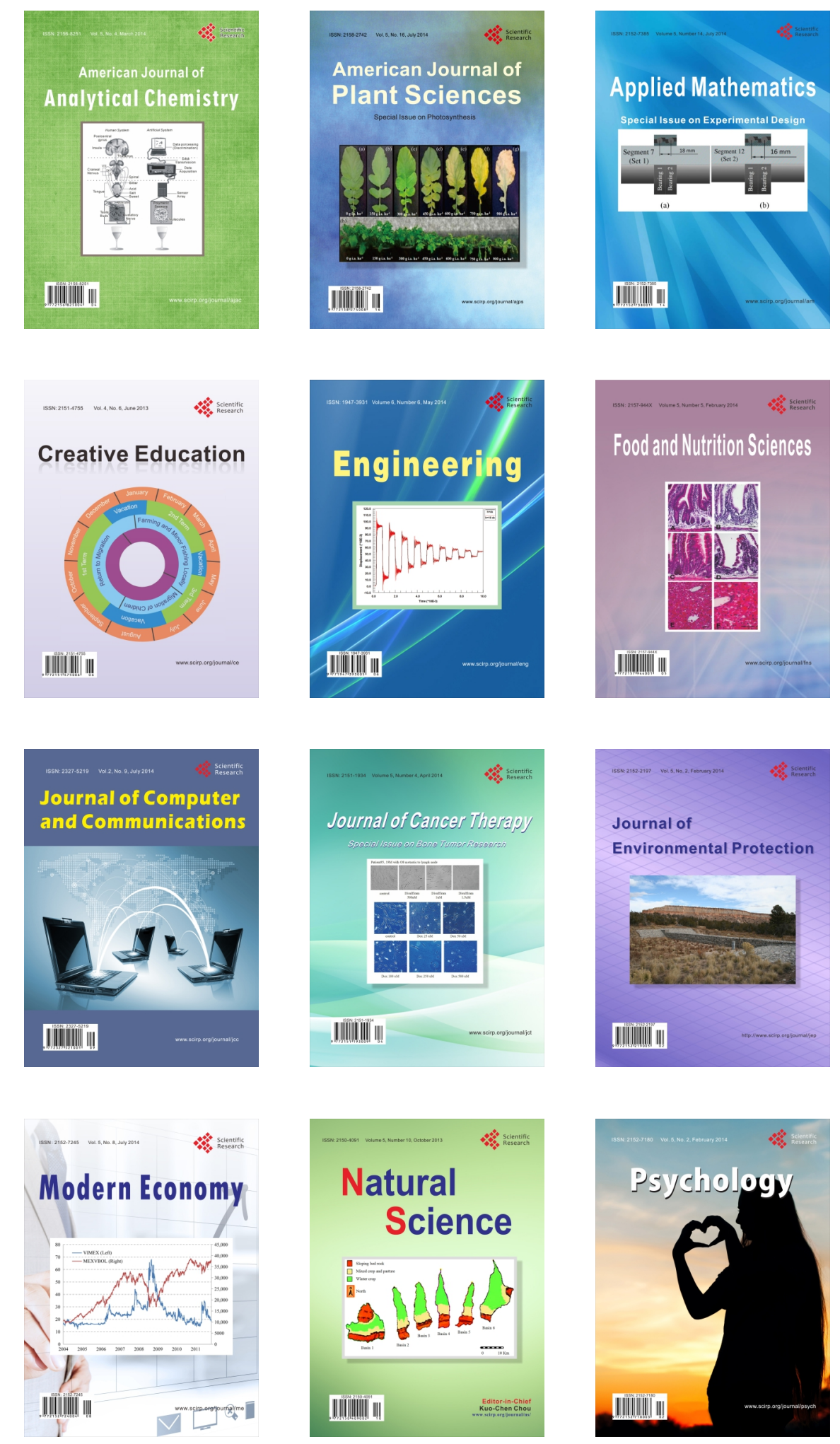